\title{
PETROGRAPHY AND PROTOCLASTIC STRUCTURES OF THE ORBICULITE BOULDERS FROM SÄÄKSLAHTI, TOIVAKKA, FINLAND AND THE MAGMATIC GENESIS OF ORBICULITES
}

\author{
Tapani Mutanen
}

Mutanen, Tapani 1974: Petrography and protoclastic structures of the orbiculite boulders from Sääkslahti, Toivakka, Finland and the magmatic genesis of orbiculites. Bull. Geol. Soc. Finland 46, 53-74.

Firstly, two of the many orbiculite boulders found at Sääkslahti are described. The matrix of the orbiculites varies from diorite to quartz monzonite. Orbicule are compositionally heterogeneous (from essentially plagioclasic through all kinds of intermediate types to hornblendic), and often they are protoclastically deformed and disrupted.

Mineral paragenesis, structures and textures clearly indicate a magmatic origin. Later metamorphic events are manifested by the formation of uralite, secondary biotite and titanite, chlorite, sericite and prehnite.

A mechanism for orbicule formation in magmas is presented. An orbiculeinclined magma possesses a low oxygen pressure, which is indicated in the low ratio of ferric to ferrous iron in the orbicule occurrences analyzed. The low oxygen pressure inhibits the nucleation of early spinels, which are detrimental to the evolution of delicate orbicules. In a fluid, turbulent magma, proto-orbicules were generated through synneutic accretion of phenocrysts (glomerophyric structure). These groupings, and sometimes individual single phenocrysts and xenoliths, were centres for the precipitation of shells, by creating local temperature and attraction gradients. From a zone around these local centres an excess phase (in relation to the cotectic or eutectic) diffused and crystallized on the proto-orbicule. This, in turn, caused the enrichment of the components of the other phases in the diffusing front, until they became saturated and crystallized, forming the next zone. Then, again, the first phase began to crystallize. Supercooling prevailed during the process, causing the formation of one-phase shells. Now and then granular »shock-layers» formed. The rhythmic zoning represents a special case of some types of rhythmic igneous layering. Radial arrangement of minerals was formed by the principle of crescumulate growth. Free space was necessary for the radial mineral growth which is shown by many natural examples and experimental silicate synthesis and zone melting.

The mechanism of hailstone formation is nearly identical to the orbicule formation in magmas. Hailstones also possess the same textural and structural features as terrestrial orbiculites. Wiborgitic rapakivi granites must also be 
classed as orbiculites, being formed by the same mechanism as the more delicate orbiculites.

Finally an attempt is made to distinguish between magmatic, metamorphic and metasomatic orbiculites.

Tapani Mutanen, Geological Survey of Finland, 02150 Otaniemi, Finland.

\section{Introduction}

Orbiculites ${ }^{1}$ ) present a much debated petrogenetic problem. Of course, almost any geological paper could be commenced with a phrase like this. Peculiar to orbiculites is the fact that a specific explanation may well apply to one orbicule, but perhaps not to its fellow, or to the relations between orbicules and matrix.

It is somewhat surprising to note how little attention the structures have drawn in orbicule literature, old classic works excluded. In gene-

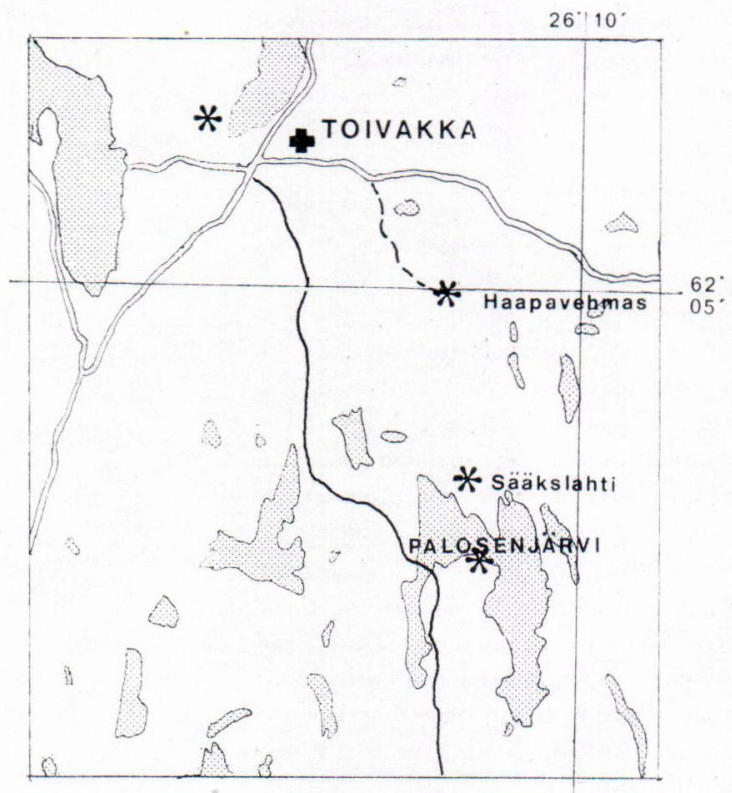

$5 \mathrm{~km}$

Fig. 1. Location of the orbiculite boulder finds (asterisks) in Toivakka. tic considerations many important structural pecularities have been neglected or, at best, forcedly interpreted to support metasomatic views. In particular, protoclastic macrostructures have frequently been passed by, if inappropriate to the solid-state model used.

Signs of protoclastic phenomena seem to be very characteristic of, if not fundamental to, orbiculite occurrences (see e.g. Sederholm 1928, pp. 13, 26-27, 44, 61, Pl. V, Fig. 1, Pl. IX, Fig. 1 and Fig. 2, Pl. X, Fig. 1 and Fig. 2; Johnston 1936, pp. 420-421; Eskola 1938, pp. 470-471; Hiessleitner 1951-1952, p. 380; Barrière et al. 1971, p. 407; Bussen and Sakharov 1971; cf. also: Knight and Knight 1971, p. 100). Such features, occurring in a striking fashion (Figs. 6, 7), attracted my attention in several dark orbiculite boulders, found around the farm Sääkslahti in Toivakka, Central Finland. In the following, two of the boulders are first described. Then, in the light of these findings and other similar or related features presented in literature, the genesis of orbiculites is reappraised.

\section{Location of the orbiculite boulders of Sääks- lahti, and their relation to other orbiculite finds of the area}

The location of the orbiculite boulders of Sääkslahti, with other occurrences of the area, is shown in Fig. 1.

At the farm Sääkslahti about ten glacial boulders of orbiculite are found, ranging from a few

1) Sederholm (1928, p. 72) introduced the term orbiculite for dioritic orbicular rocks. Orbicular oligoclase diorites were designated by him as esboites. The term orbiculite is, however, too convenient for such restricted use. Furthermore, etymologically orbiculite is synonymous with orbicular rock. Here the term orbiculite is used for rocks of any composition that possess orbicular structures. 
$\mathrm{dm}^{3}$ to about half a cubic metre in size. By inference from the smoothed edges, the boulders have travelled a moderate distance. It seems probable that the orbiculite boulder finds of $\mathrm{Pa}$ losenjärvi, Sääkslahti and Haapavehmas have a provenance in common, belonging to the same boulder fan. The three boulders at the farm Haapavehmas, known to me, are quite big and angular; the bedrock source is probably to be found not far from the northernmost boulder, which is several cubic metres in size. This at the same time is the most attractive in appearance, having fist-sized orbicules tightly crowded together, almost without any matrix. Visually it is much like the Palosenjärvi orbiculite.

I have not been acquainted with the fourth orbiculite boulder find, situated west of the church, so its relation to other finds remains unresolved here.

\section{Petrography}

In the following account two of the many boulders of Sääkslahti are described, which, I hope, elucidate features fundamental to genetic interpretations.

Observations are made on sawed slabs and thin sections. Opaque constituents have not been studied. They are altogether lacking in most of the thin sections and very scanty in the rest, so their contribution to the quantitative mineralogy is insignificant, as is also their paragenetic importance (if not their scarcity, see pp. 66-67).

The boulders are called »the small boulder» and "the big boulder", $0.3 \times 0.3 \times 0.4 \mathrm{~m}$ and $0.7 \times 0.7 \times 0.9 \mathrm{~m}$ in size, respectively.

In the s mall boulder (Figs. 2 and 3) protoclastically broken, flattened and twisted orbicules are unevenly distributed in the matrix,

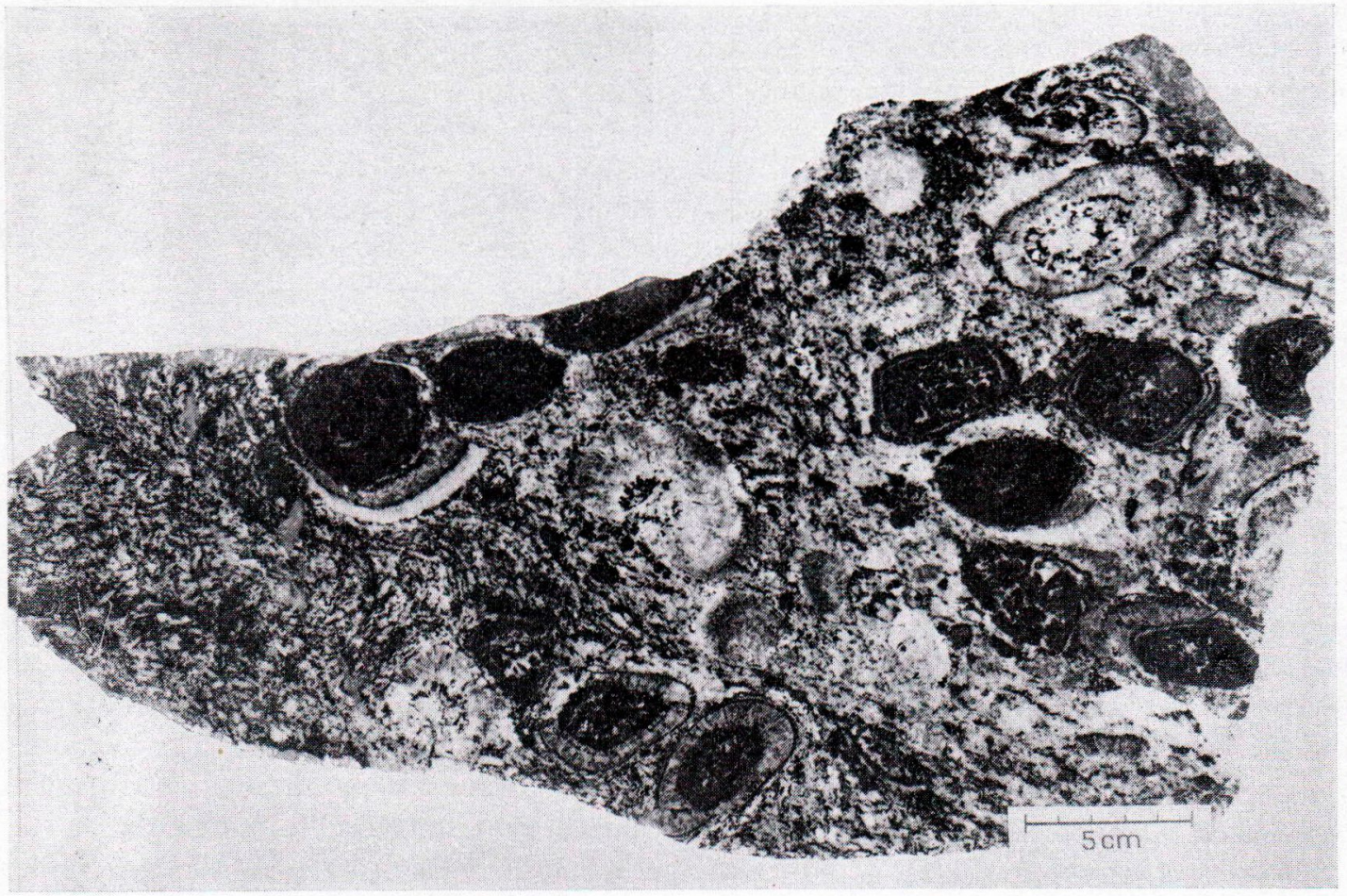

Fig. 2. The small orbiculite boulder. Light proto-orbicules, melanocratic, mesocratic and leucocratic completed orbicules, shedding orbicules and residual cores are to be seen.

Photo Erkki Halme. 


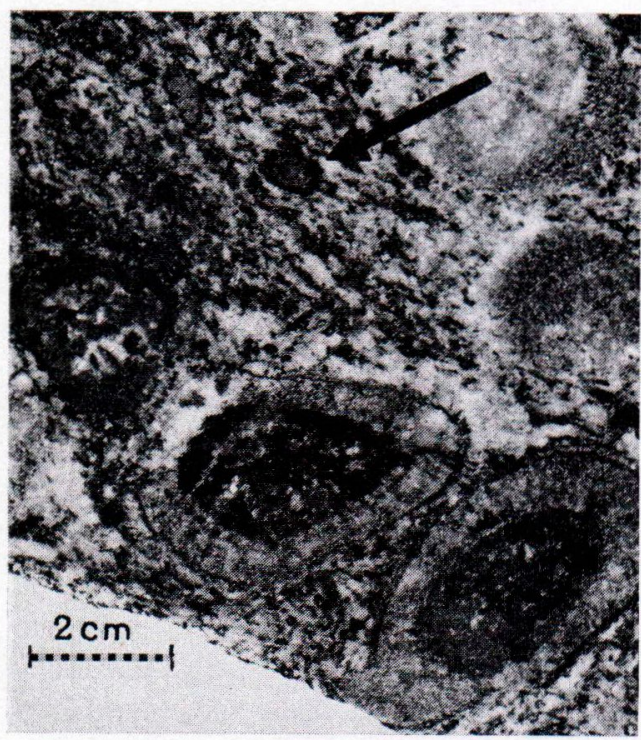

Fig. 3. Part of Fig. 2. Uralite phenocryst shown by arrow. Photo Erkki Halme.

the structure of which varies from massive to banded. Varying grain size and colour index also contribute to the heterogeneous appearance of the matrix.

Microscopic examination reveals that the matrix is even more heterogeneous in composition than could be guessed from the variation in colour index. The petrographic composition varies from hornblende dioritic to hornblende quartz monzonitic, with a rather small amount of plagioclase in the latter variety.

Plagioclase (calcic oligoclase - andesine), hornblende $\left(\gamma=\right.$ bluish green, $\left.\gamma \wedge \mathrm{c}=18^{\circ}\right)$, potash feldspar (at least in part microcline) and quartz are the main constituents. Biotite $(\gamma=$ dark brown to brown, sometimes greenish brown) is always scanty. Accessory minerals are titanite, apatite, allanite, zircon and opaques. Secondary alterations are common: carbonate, sericite and epidote have formed at the expense of plagioclase; biotite is partly altered to chlorite and prehnite. Uralite phenocrysts indicate that hornblende, at least in part, is formed from clinopyroxene, relicts of which are preserved. Hornblende aggregates, occurring together with uralite phenocrysts (Fig. 4) and often having biotite-rich margins, may also represent uralitized and recrystallized clinopyroxene phenocrysts or synneutic groups of phenocrysts. Biotite seems to have been formed in part at the expense of hornblende. Titanite occurs in two generations. The older titanite is strongly pleochroic, contains metamict inclusions of an unidentified mineral and has broader pleochroic halos than the younger titanite, which also has a weaker pleochroism. The latter type occurs in conjunction with hornblende and biotite, and is probably a by-product of uralitization.

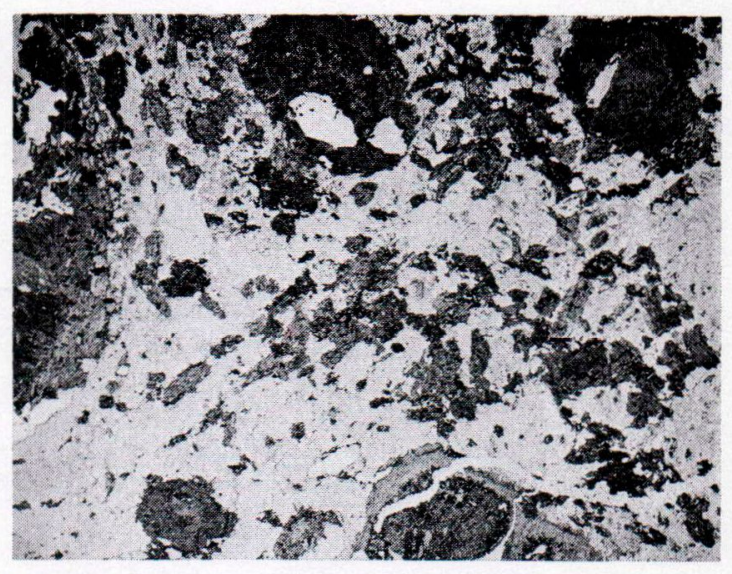

Fig. 4. Uralite phenocrysts with relict clinopyroxene cores. Left, biotite rimmed hornblende aggregate. // nicols. X 3.5.

Photo Erkki Halme.

Thus the whole paragenesis has suffered metamorphic events, beginning with uralitization of clinopyroxene and ending with the prehnitization of mica. Some amount of $\mathrm{K}_{2} \mathrm{O}$ from the potash feldspar participated in the migrating fluid phase and caused biotitization of hornblende. At the same time the primary orthoclase perhaps inverted, through solution, to microcline. In Finnish orbiculites metamorphic overprints are common, if a sensible paragenesis is available (see e.g. Eskola 1938).

The matrix texture is blasto-hypidiomorphic or granular. Plagioclase is mostly anhedral, but 
it also occurs as subhedral laths, up to $3 \mathrm{~mm}$ long, composed of Carlsbad twins. The euhedral form of clinopyroxene is visible in uralite phenocrysts ( $\varnothing$ up to $10 \mathrm{~mm}$ ); otherwise the matrix hornblende is anhedral. Potash feldspar occurs both as interstitial microcline and as isometric, angular grains $(\varnothing 1.5-2 \mathrm{~mm})$. In the latter cross twinning is not commonly visible. Quartz fills interstices between other constituents and always shows an undulous extinction.

The examination of the matrix gives an impression of a magmatic rock, which has later suffered regional metamorphism. Clinopyroxene and plagioclase were the first to crystallize. Their phenocryst-like appearance indicates a comparatively high intrusion level. Potash feldspar and quartz, with some hornblende, crystallized last from the melt, but plagioclase was almost wholly consumed at that time.

The orbicules may be classed in different ways. According to colour index, we can discern Jeucocratic, mesocratic, melanocratic and ultramafic orbicules and contrasting divisions of orbicules (e.g., an ultramafic core with a leucocratic shell). According to the state of formation or destruction the following types are to be seen: protoorbicules, completed orbicules, degenerating orbicules and residual orbicules. The most common are melanocratic and ultramafic orbicules which are often disrupted. Undamaged types are multishelled but rather simple. In a single sawed slab (Fig. 2) five or six orbicule types, commonly situated side by side, can be seen.

Besides the orbicules proper other kinds of mineral groupings occur in the matrix: obscure or identifiable shell fragments, ultramafic mineral aggregates, roundish orbicule-like aggregates, and phenocrysts. The size of ultramafic aggregates ranges from single phenocrysts (see Fig. 3) and aggregates of about the same size, described above, to big ( $\varnothing$ up to $20 \mathrm{~cm}$ ) roundish lumps. All ultramafic aggregates have sharp boundaries and no distinct shells. Genetically they are either normal or over-grown synneutic proto-orbicules, or residual, i.e., completed and subsequently peeled orbicules (p. 59). Roundish orbicule-like leucocratic aggregates may likewise be classed as proto-orbicules. Three or four such aggregates are visible in Fig. 2. They have indistinct borders against the matrix, and often contain mafic minerals as inclusions, arranged in a vague zone around the centre.

Plagioclase and hornblende dominate among orbicule minerals. The former, calcic oligoclase to andesine in composition and in places turbid from alteration products, occurs as radially arranged laths with fine albite twinning (Fig. 5). Radial plagioclase zones sometimes include anhedral, clear oligoclase, which may have been formed through recrystallization of the primary radial plagioclase. Hornblende also occurs now and then in radial plagioclase as concentric zones of inclusions, suggesting temporary simultaneous precipitation of the minerals named. The same relationship between plagioclase and biotite is to be found in esboites (see Sederholm 1928, p. 32).

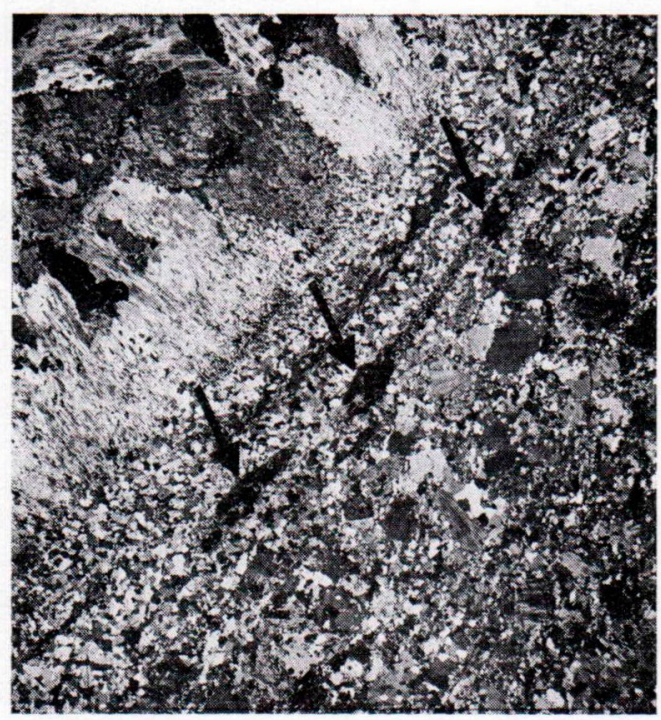

Fig. 5. Radial plagioclase from a leucocratic orbicule. Arrows point to sericite-rich lenses in the outer shell, where microcline (?) is present in small amounts. + nicols. X 3.5.

Photo Erkki Halme. 
There are also narrow zones, composed of granular and evidently primary plagioclase. These zones are not included in, but interrupt, radial zones.

The hornblende of the orbicules is of the same common bluish green quality as that in the matrix. In a few cases radial arrangement is to be noticed under the microscope and even with the naked eye. Possibly this arrangement is inherited from the former pyroxene. Radial pyroxene has been met with in terrestrial orbiculites (Carstens 1957, p. 279), and it is a characteristic feature of chondrite meteorites.

Biotite is very rare in orbicules. In one case a discontinuous biotite shell occurs in a mesocratic orbicule.

Analogous to hailstones (see p. 65), coarse radial shells represent moderate supercooling and slow growth rate, whereas granular zones with smaller grain size, equivalent to the air bubble inclusion zones of hailstones, have crystallized rapidly from a strongly undercooled magma (Knight and Knight 1971, p. 102; cf. the opposite opinion, Barrière et al. 1971, p. 410).

The lack of quartz and potash feldspar in the orbicules is noteworthy. In reality, in the outer granular plus radial plagioclase shell of an orbicule there occurs an interlocking, colourless low-relief mineral, which may be potash feldspar. It participated in the completion of the orbicule formation (see p. 69). In this same zone turbid, sericite-rich lenses and ribbons occur (Fig. 5).

In the Lintusaari orbiculite, which is quite similar to those under consideration in both composition and structures, no potash feldspar occurs in the orbicules (Eskola 1938, p. 470). The orbicules of the Kangasniemi rock often show strong enrichment of potash feldspar in the outer salic zones (Sederholm 1928, p. 38). As a general rule, potash feldspar strongly favours the matrix in orbiculites, and is usually lacking in the orbicules. This must be borne in mind in discussing orbiculite genesis (p. 69).
Because of the great demand for the slabs. sawed from the big boulder, it was not possible to get samples for thin sections from the desired places.

The orbicules are swimming loosely in the matrix with an uneven distribution. The matrix is coarse grained and massive. The occurrence of two kinds of matrixes is interesting. The lighter matrix (colour index 23) is separated from the darker (colour index around 60) by a distinct, nearly sharp boundary (not a fault, nor a joint). Orbicules are concentrated in the dark part, but some orbicules occur also in the light part. A visual estimation of the mean colour index of the rock, taking the orbicules into consideration, gives the impression that differences in colour indexes between the light and the dark part become smoothed, as if the matrix had been differentiated into orbicules (lighter than average) and matrix (darker than average); the light matrix variety with sparse orbicules would represent the undifferentiated magma. The sharp boundary between the two kinds of matrixes may be due to magmatic flow. The mechanism of differentiation will be discussed later (pp. 63-64).

Both kinds of matrixes are dioritic. The lighter matrix contains a small amount of quartz and microcline, which have not been found in the dark matrix variety. Plagioclase in both is calcic oligoclase $\left(\mathrm{An}_{30-20}\right)$. It occurs as euhedral, isometric grains, and as $2-4 \mathrm{~mm}$ long laths. Albite twinning is always present, pericline twinning is more rare. Many laths are composed of Carlsbad twins. Hornblende $(\gamma=$ ordinary green) is at least in part uralite, which is indicated by clinopyroxene relicts. Biotite $(\gamma=$ dark greenish brown) is more plentiful in the dark matrix. Titanite, allanite, apatite, zircon and rare opaques are accessory constituents. Secondary alterations are of the same kind as in the small boulder. Plagioclase was altered to sericite, epidote and carbonate; biotite to chlorite.

It is evident that the matrix rock is magmatic in origin. The primary hypidiomorphic-granular 
texture is still discernible, in spite of metamorphic alteration and recrystallization. The composition is more $\mathrm{K}_{2} \mathrm{O}$-poor than that of the small boulder. But as only two thin sections were available from the big boulder, and in view of the heterogeneity of the matrix in both boulders, we can assume that these boulders have a common provenance.

The orbicules macroscopically resemble those of the small boulder. They can be roughly divided into two types: small $(\varnothing 1.5--3 \mathrm{~cm})$ ultramafic or leucocratic proto-orbicules (or partly residual?), and big (C up to $15 \mathrm{~cm}$ ) orbicules. These last are for the most part multishelled, but rather simple, sometimes composed essentially of feldspar only. Usually they have hornblende cores and alternating shells. A couple of multishelled orbicules, with a narrow plagioclase shell, are present.

Protoclasis is present in a showy manner (Figs. 6, 7).

The Toivakka area is situated in the southern part of the so called Granite Complex of Central Finland. Quartz monzonitic hypabyssal and in- trusive rocks, and compositionally similar trachyandesitic effusives, occur in the southern, southwestern and western parts of this granite area (see e.g. Marmo 1963, Table 3, analyses 13, p. 19; Marmo 1965, p. 21). Differentiation from diorite to quartz monzonite, as in the matrix of the small boulder, occurs in the Muittari complex in Saarijärvi, near the western border of the granite area (Wilkman 1936, p. 121).

\section{Protoclastic structures}

Protoclastic structures on a macroscopic scale are very characteristic of many boulders of Sääkslahti. Fig. 2 presents a lithified display of some of the protoclastic events.

Ultramafic, generally roundish hornblende aggregates are, possibly for the greatest part, residual orbicules, left after peeling off of the shells (see also Sederholm 1928, p. 61). One is caught in the very act in Fig. 2, the left part. Two others nearby have already shed their shells. Not all ultramafic aggregates, however, are such »used» cores; some are real synneutic protoorbicules.

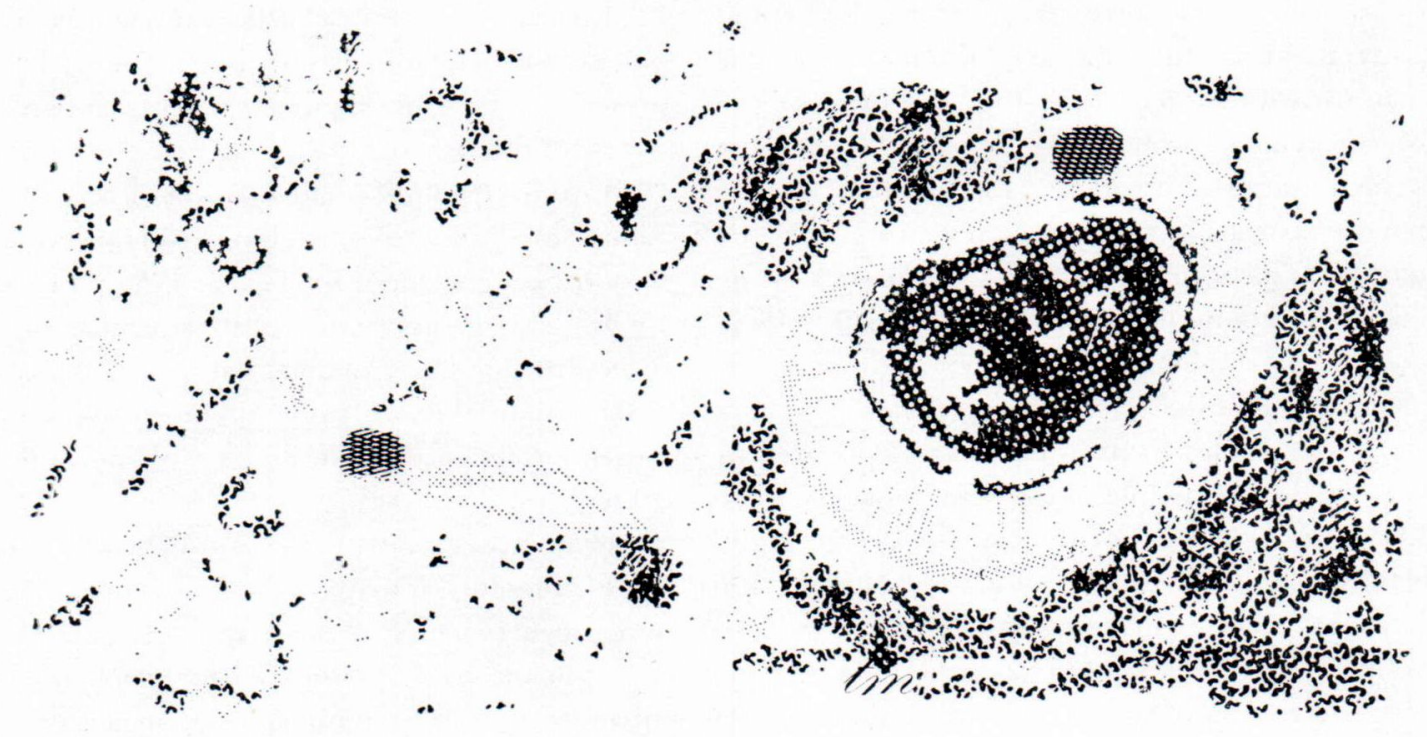

$5 \mathrm{~cm}$

Fig. 6. Damaged orbicule. Left from it a shell fragment. Two uralite phenocrysts are to be seen. Note the enrichment of mafics around the orbicule. Big boulder. 

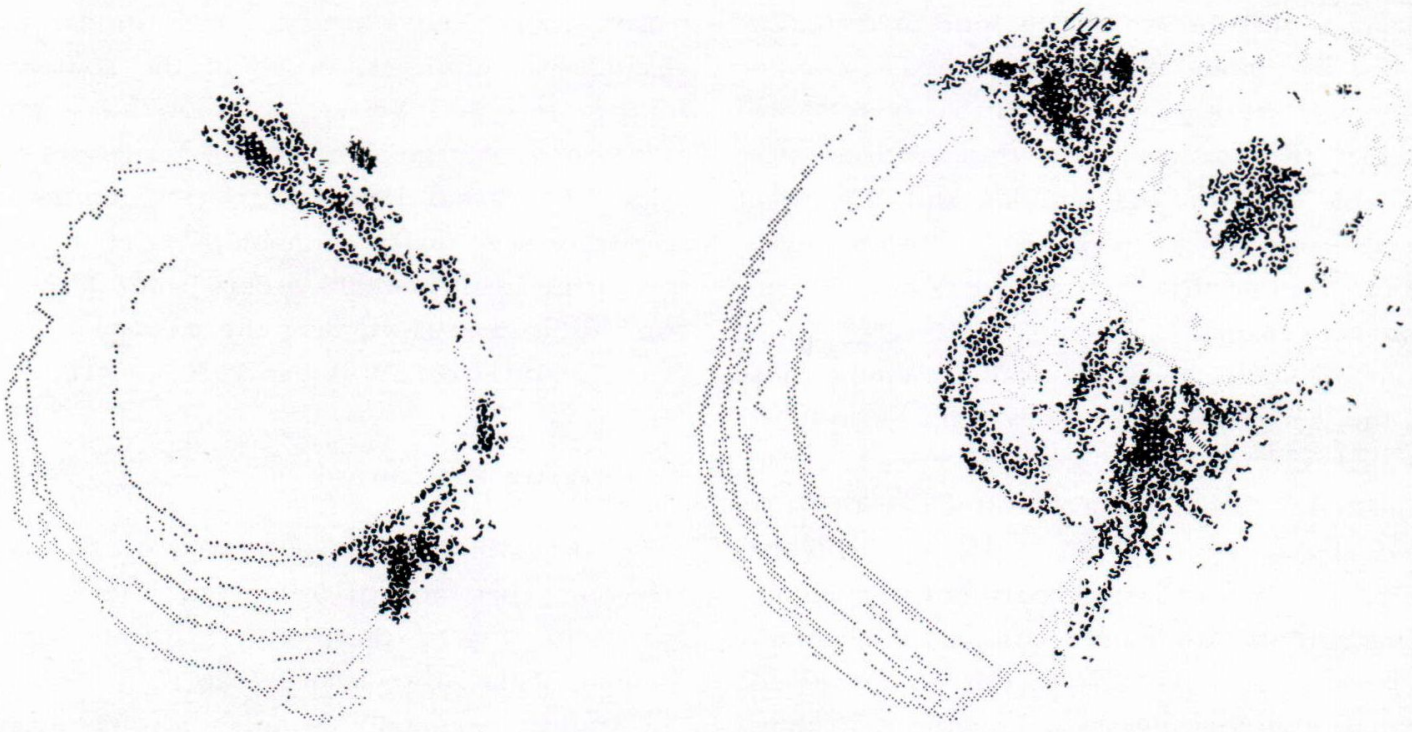

Fig. 7. Protoclastic macrostructures. Big boulder.

The locally banded structure of the matrix of the small boulder might induce an observer to suspect that all this is a demonstration of cataclasis. I hope, therefore, that Figs. 6 and 7 would convince him that we are dealing with true magmatic phenomena. In Fig. 6 a part of the big orbicule's envelope is lost. To the left of it a shell fragment is adrift. Two angular uralite phenocrysts have succeeded in getting into the picture. The enrichment of mafic minerals in the matrix surrounding the salic outer shells of the orbicule is important to the explanation of the orbiculite genesis (p. 63).

Two examples of protoclasis are illustrated in Fig. 7. Both orbicules have lost most of their envelopes. The core of the orbicule to the right is loosened and revolved, which indicates strong torsional movements in the magma ( $c f$. Sederholm 1928, Plate X, Fig. 1, and p. 42). The space left behind the core is filled partly with the common matrix-forming magma, and partly with coarse-grained feldspar, crystallized from the most mobile fraction of the residual magma (see Mead 1925, pp. 696, 697).

\section{Magmatic formation of orbiculites, with spe- cial reference to hailstones}

Magmatic theories of orbiculite genesis are as old as the orbiculite study itself. Later, in the present century, metasomatic agents apparently attacked Finnish orbiculite occurrences (Eskola 1938; Simonen 1941) and this »Holocene metasomatism» affected foreign orbiculites also (Goodspeed 1942; Conybeare 1951; Leveson 1963). The protoclastic features found in the orbiculite boulders of Sääkslahti and in others described in the orbiculite literature convinced me about the magmatic genesis of most of the orbiculites.

Metasomatism fails to explain orbicular structures, different kinds of orbicules in one and the same occurrence, and especially the wide range of compositions (e.g. from hailstones to orbicular chromite ores) met with among orbiculites. In each case a specific kind of metasomatism should be assumed. Furthermore, in spite of the wide range of chemical compositions, orbiculites possess common textural and structural charac- 
teristics. The following account is an attempt to find a universally applicable model for the formation of orbicules in magma. The matrix presents no problem in this respect, but its relation to the orbicules is important.

The evolution of magmatic orbiculites includes different stages, namely:

1) formation of proto-orbicules,

2) growth of orbicule shells,

3) crystallization of matrix,

4) possible metamorphic and cataclastic events.

During the first three stages protoclasis is possible and, in fact, very often realized.

The problem of the formation of centres, around which the shells could grow, is no more serious than the nucleation of crystals in general, Evidently different kinds of orbicule cores exist, even in a single occurrence. Xenoliths, known e.g. from the orbiculite of Kangasniemi (Sederholm 1928, p. 36) can serve as nuclei. But as the size range of orbicules in a given rock is narrow, which is not to be expected from xenolithic breccias, xenoliths certainly are not very common as cores for orbicule shells. In fact, verifiable xenoliths are quite seldom met with as orbicule nuclei. Xenolithic reaction-rim orbiculites are readily distinguished from those in which the cores have been chemically passive (p. 70). But, according to the presentation that follows, the "provenance» of the nucleus is not essential to the formation of a complete orbicule. This independence is shown particularly impressively by the rhythmic layering around autoliths as well as xenoliths in the Willow Lake intrusion, with perpendicular mineral arrangement quite identical to that of orbiculites (Poldervaart and Taubeneck 1959; Taubeneck and Poldervaart 1960).

The most common kind of orbicule cores seem to be synneutic groups of phenocrysts or individual phenocrysts. This is clearly illustrated in a recent paper by Barrière et al. (1971). There
Figs. 3 a and 3 c (p. 408) present orbicule cores composed of single megacrysts. In Fig. $3 \mathrm{~b}$ two megacrysts have seemingly synneutically adhered together. Eskola (1938, pp. 465, 470) described similar features from the orbiculites of Lintusaari and Kangasniemi. He noted that the orbicule tends to retain the form of the central nucleus, as do the orbicules described by Barrière et al. (1971). In the latter paper (Fig. 3 b), the existence of two core crystals is likewise revealed by the form of the orbicule, as in the case of an egg with two yolks ( $c f$. also: Sederholm 1928, Plate VI, Fig. 2).

Synneutic phenomena seem to be very common in wiborgitic rapakivi granites, which really are true single-shelled (and sometimes multishelled; Wahl 1925, p. 59) orbiculites. From this magma plagioclase was first to crystallize (Vorma 1971, p. 59). According to Vorma (op. cit., pp. $24,25)$, euhedral plagioclase occurs as inclusions in potash feldspar ovoids, just as in the orbiculites mentioned above. Sometimes inclusion material forms a granitic aggregate in an ovoid's nucleus (op. cit., p. 26). Vorma has met with even granitic orbicules, mantled by potash feldspar. Most often the ovoids are composed of more than two sectorially grown alkali feldspar grains (op. cit. p. 22), which Vorma regards as possibly having been formed through synneusis, as well as the plagioclase aggregates in tirilites and wiborgites (op. cit., p. 7). We may regard the wiborgite structure as representing a glomerophyric structure, with a step (oligoclase shells) towards orbiculites proper. It is interesting that besides the sectorially grown feldspar in rapakivi ovoids, radial arrangement of plagioclase occurs in a glomerophyric monzonite, described by Sukhorukov (1972, p. 79).

Turbulent flow is the necessary condition for synneusis (Vance 1969 , p. 26). Such a condition is established in small conduits and near the walls of an active intrusion. The orbiculite-like formation along the inner contact of a diabase dyke in Bornholm, described by Callisen (1934, p. 168), bears witness to the important role of active, 
turbulent flow in orbicule formation. Sederholm (1928, p. 53) has noted that strong turbulence was effective during the orbicule formation of the Stockholm orbiculite. Describing the immature orbicular norite of Romsaas, Norway, Carstens (1957) has considered the role of turbulence and associated synneusis.

In the flowing magma orbicules accumulated due to gravity and (or) flow differentiation in elongate bands (Barrière et al. 1971, p. 409 and Fig. 1, p. 406).

Protoclastic deformation is the very best evidence of turbulence. In the early stages turbulence produced the proto-orbicules. During the later stages it acted destructively, deforming and brecciating completed orbicules (see e.g. Gon'shakova 1961, p. 82-83).

With the active flow in the orbicule-generating magma in mind, I suspect that many of the banded structures of orbiculite matrixes have been erroneously interpreted as migmatite structures. I have never seen proof of true palaeosomes and corresponding neosomes in orbiculite samples or in descriptions of "migmatic» matrixes of orbiculites. Nor has anybody, as far as I know, claimed that banded chromite ores are migmatites, in the sense in which most geologists understand its meaning. It is hardly mere chance that banded chromite ores and orbicular chromites occur side by side (see Johnston 1936, pp. 420-421; Shams 1964, p. 1345). The orbiculite of l'Aber-Ildut, with a distinctively banded matrix, has been shown to be truly magmatic (Barrière et al. 1971) and is very similar to many other occurrences, obscured by later metamorphism.

Synneusis and associated protoclasis can explain the formation of the peculiar droplets in the ovoidophyre of Lujavrurt, explained as baving been generated through liquid immiscibility (Bussen and Sakharov 1971). The balls, lenses and ovoids of that rock may have been protoclastically deformed into those droplets during the magmatic flow. The plagioclase tails of basic orbicules, described from the Lone- some Mountain area by Leveson (1963, Fig. 6, p. 1025), are probably another example of the same phenomenon. In the ovoidophyre of Lujavrurt, furthermore, crystal fragments in the matrix and signs of cataclasis in the ovoids are said to occur (Bussen and Sakharov 1971), which are probably evidence of protoclasis. This peculiar rock, besides typical shelled ovoids, shows many features characteristic of »common» orbiculites, such as radial feldspar in ovoids. Without any doubt it is a true magmatic rock.

Accordingly, it seems plausible that purely mechanical factors are the most fundamental to the formation of proto-orbicules. This is particularly well indicated by the occurrence of "positive» and "negative» orbiculite types in one and the same occurrence. Thus in the boulders of Sääkslahti, compositionally extreme orbicules can be found side by side, besides the intermediate types. Olivine orbicules with chromite matrix and chromite orbicules with olivine (now serpentine) matrix (Hiessleitner 1951-51, p. 382; Shams 1964, Figs. 4-6, p. 1344) present another, even more illuminating example.

If turbulence alone is able to build synneutic groups of phenocrysts, which serve as centres for later shell precipitation, then such »protoorbiculites» should be more common than »developed» ones. In fact they are. The wide occurrence of glomerophyric structures and other kinds of mineral segregations really represent the first stage of the formation of orbiculites proper. Now and then, as in the boulders of Sääkslahti, proto-orbicules occur together with more developed shelled orbicules. Thus the conditions necessary to generate proto-orbicules were intermittently repeated all the time the orbicules were forming. Carstens (1957) described a similar case (see also Sederholm 1928, p. 54). It is highly significant to the genesis of wiborgites, that mafic balls occur in places among shelled potash feldspar ovoids (see Wahl 1925, p. 60). So wiborgites resemble other orbiculites, both externally and genetically. 
Synneusis alone, however, is not able to produce rhythmically precipitated shell divisions. Rather, the result would be a chaotic aggregate of those minerals which are crystallizing from the magma. To take an example from rapakivis again, shelled granitic balls (Wahl 1925, p. 59; Vorma 1971) could represent a kind of synneutic accretion.

Rosenbusch (1887, p. 120) has already presented a trustworthy solution to the shell problem (applied later by Sederholm, 1928, p. 25). It implies crystallization of a phase, say pyroxene, with resulting enrichment of the components, not entering to the pyroxene composition, in the surrounding magma. When the magma reached the saturation level of the next phase to be crystallized, say plagioclase, this precipitated, forming a shell on the formerly crystallized pyroxene. Then pyroxene again began to crystallize from the homogeneous melt. And so on.

In Fig. 8 a kind of proof of the Rosenbusch idea is presented. The crystallization of the mafic orbicule-core had caused the enrichment of the plagioclase components in the surrounding magma. The attempt to form a shell from this plagioclase-rich material was interrupted by the solidifying of the magma. Comparable enrichment of mafics around the plagioclase-rich shell division is to be noted in Fig. 6.

Very similar thoughts to those of Rosenbusch have been presented, obviously independently, to explain the genesis of rhythmic layering in magmatic rocks (Wager 1959, p. 77; Vlasov et al. 1959, p. 593 - 594; Taubeneck and Poldervaart 1960 , p. 1316 - 1317; Wager 1963, p. 4; Wager and Brown 1967, p. 273; Valyashko and Agoshkov 1970, p. 36-37; Yaroshevskii 1970, p. 562 --563; Sharkov 1971, p. 70-71) and rhythmic zoning in hypabyssal granitic bodies (Povilaitis 1961, p. 48). Koptev-Dvornikov and Yaroshevskii (1970) through experimental zone melting and crystallization proved the capacity of alternating impoverishment and saturation plus crystallization to produce rhythmic layering, identi-

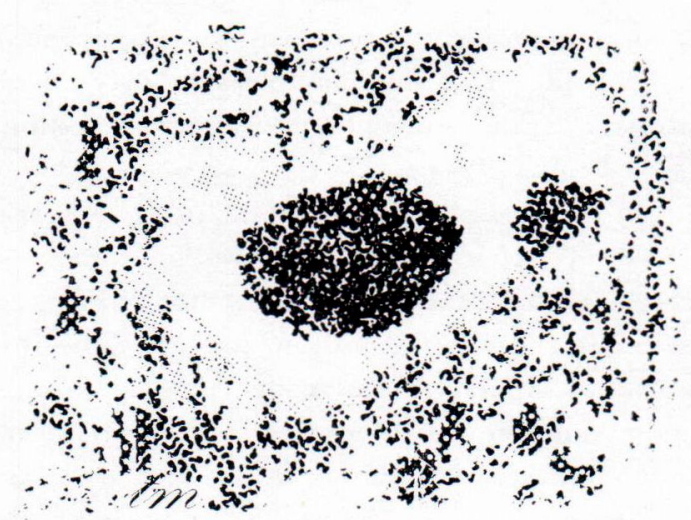

Fig. 8. Interrupted shell formation. The magma solidified before plagioclase, enriched around the mafic protoorbicule, could order itself into a perfact shell.

Big boulder. Natural size.

cal to that met with in orbiculite shells and igneous layering.

The above principle should lead to the alternating crystallization of an excess phase and subsequent eutectic or cotectic precipitation of corresponding phases. But we have found that alternating monomineralic shells are very common among orbiculites. Evidently supercooling is an important factor in the genesis of magmatic rhythmic sequences (van Zyl 1959, p. 26-27; Poldervaart and Taubeneck 1959, p. 1396; Taubeneck and Poldervaart 1960, p. 1316-1317). In the experiments made by Koptev- Dvornikov and Yaroshevskii (1970) diopside crystallized alone in monomineralic layers, and anorthite before diopside in two-phase layers. These phenomena indicate supercooling (op. cit., p. 714).

The thicknesses of the alternating rhythms evidently depend on the velocity of diffusion, but also on the tolerance of the phases to oversaturation. Thus individual rhythms are broader, the hotter and more fluid the magma, and hence the broader is the diffusion front. On the other hand, the closer alternation of shells in esboitic orbicules, as compared to the more basic andesine-pyroxene-hornblende orbiculites, may be due to lower temperatures, but also results because biotite may crystallize more perceptibly 
from undercooled liquids than does pyroxene or hornblende. This kind of tolerance may be expressed as the concept "power of nucleation» (see Wager 1959, p. 77).

On the ground of the speculations, observations and experimental facts presented above, I conclude that orbicule shells resulted from alternating local supersaturation and crystallization ahead of crystallization fronts. The monomineralic shells represent the crystallization of the excess phase, or, when the magma is oversaturated in a few phases, the phase with the greatest nucleation power. The two-phase layers resulted from eutectic or cotectic crystallization, usually with prior oversaturation of either phase.

But why did this kind of rhythmic crystallization not produce igneous layering? Here we must consider the cooperation of synneusis and rhythmic crystallization, which is extremely important to the genesis of typical orbiculites:

Proto-orbicules, either xenoliths or autoliths, formed through synneutic accretion, created local thermal and attractional gradients in the magma, which made the rhythmic precipitation around these centres possible ( $c f$. Beasley and McKinney 1973, p. 33 and fig. 7, p. 37). As mentioned before (p. 61), the rhythmic layering around xenoliths and autoliths with perpendicular mineral arrangement in the Willow Lake intrusion is an illustration of the principle that caused the formation of orbicule shells in magmas.

It is now easily realized that the provenance of the nucleus material is of no importance to the orbiculite genesis. The core acted only physically, and was chemically passive (Barrière $e t$ al. 1971, p. 409).

Turbulence was probably important in regulating the shell formation, by relaxing the crystallization of the supersaturated phase(s), which deposited as granular shells. Furthermore, turbulence stirred the magma and thus levelled compositional differences in it. But more often the influence of the active flow was destructive to the formation of orbicule shells. Radial growth occurred in a stagnant magma, between intermittent movements of the melt.

Concerning the viscosity conditions necessary to the orbicule formation, Sederholm (1928, pp. 65-66) regards high viscosity as a qualification of an »orbicule-minded» environment. This is opposite to our experience that the number of crystallization centres is greater, and hence, the grain size smaller, the more viscous the magma. As the crystallization centres at the time of orbicule formation were sparse, we can safely agree with Barrière et al. (1971, p. 410) that the magma must have a low viscosity to generate orbicules. It should be emphasized here, that the greatest number of orbiculites known are basic or intermediate, rather than acid. Acid magmas also show the smallest and most immature orbicules (as viborgite ovoids), if any. The cessation of shell formation was associated with the acidification of the residual magma, i.e., with the increase of viscosity (as in the rocks of Sääkslahti and Kangasniemi).

The most common kind of orbiculites must be considered now, at last, namely hailstones. They may be regarded as magmatic, or low temperature hydrothermal rocks. Usually they are small and rather simple in structure (comparable to crystals in common terrestrial igneous rocks); now and then bigger individuals are met with ("wiborgitic" showers!). Huge hailstone orbicules, as that in Fig. 9, are fortunately very rare. The largest hailstone ever collected, found at Coffeyville, Kansas, weighed $12 / 3$ pounds and was about $15 \mathrm{~cm}$ in diameter (Knight and Knight 1971).

Hailstones are dangerous, but they may also help in seeking answers to the genesis of lithic orbiculites. It is very surprising to note that many hypotheses concerning the genesis of hailstones are quite similar, even identical to those by which rhythmic igneous structures have been explained. Macklin et al. (1970, pp. 481, 483-485) consider that hailstone shells may have been formed when the balls encountered 


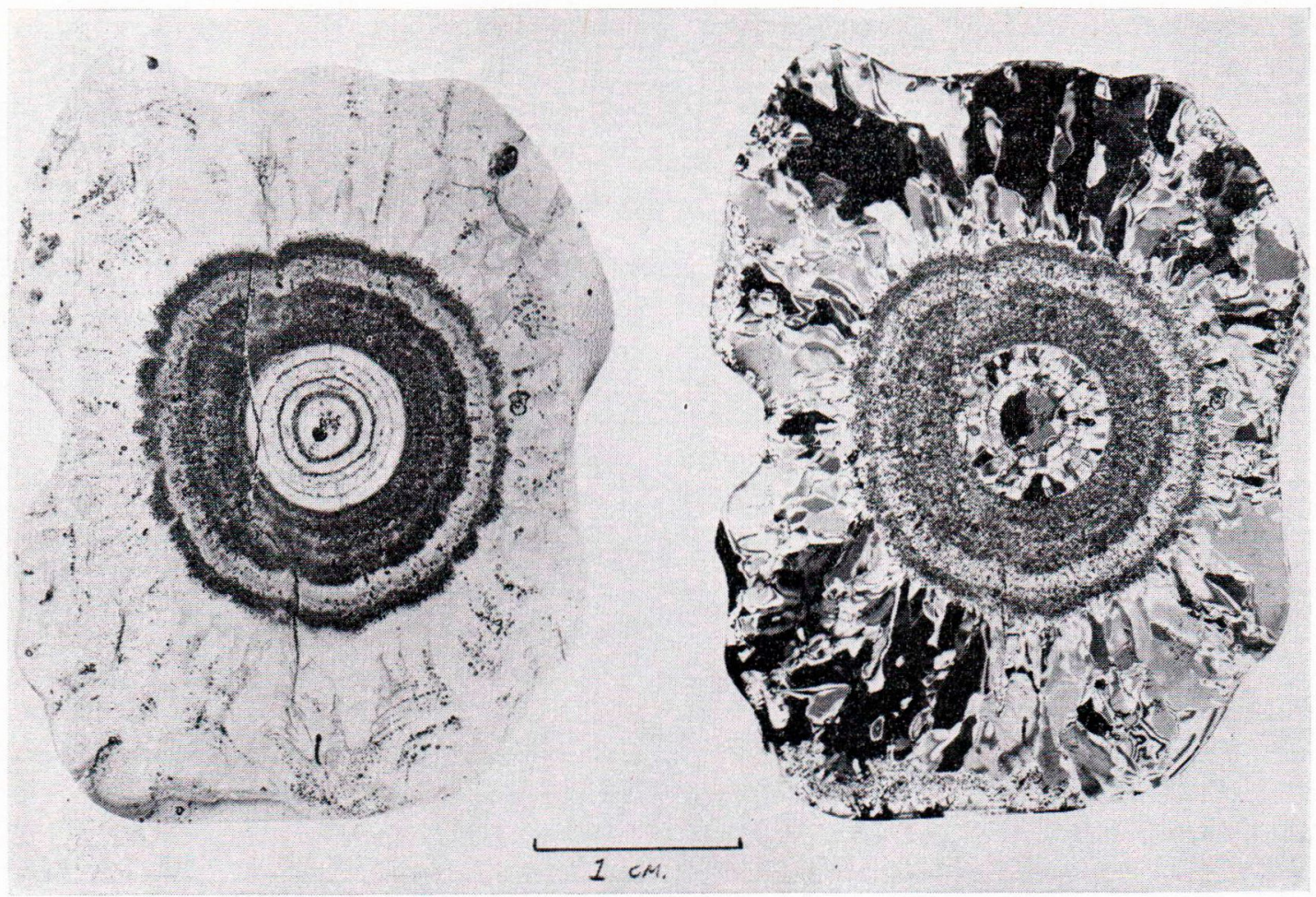

Fig. 9. Hailstone from Coffeyville, Kansas. Zones rich in air bubbles appear dark.

Photo Charles A. and Nancy C. Knight.

varying $\mathrm{P}$ - T-conditions during their journey in the updraught. Geologists are familiar with the fact that sudden release of the vapour pressure in magma is capable of causing rapid crystallization of phases and changing the order of crystallization. According to Levi (1970) pronounced hydrostatic instability is necessary for hailstone formation, which instability naturally causes a high updraught speed. Likewise active flow favours orbicule formation in magmas. Fundamental to hailstone genesis is supercooling of water droplets down to $-15^{\circ} \mathrm{C}$ and even lower (Knight and Knight 1971, p. 98). Hailstones grow »by sweeping of supercooled drops that have not frozen. No doubt they also sweep up occasional ice particles, but this is certainly a minor mechanism of growth.» (op. cit., p. 98). Similarly, the contribution by synneusis seems to be of little importance in building the shell divisions in terrestrial orbiculites. Further, List et al. (1968, p. 1974), hardly aware of Rosenbusch's ideas, state: "Of particular importance is the conclusion that the degree and variation of free water depletion - - can account for the growth of hailstone shells. - - (p. 1965:) Icing conditions, which are dependent on free water content, could change very easily at one level and help to explain the shell growth of hailstones. .».

Sederholm (1928, p. 38 and Fig. 8, p. 37) described and explained orbicules which initially contained interstitial magma. This interstitial magma was later extruded from the interior of the orbicule, in much the same way as trapped water is expelled from spongy hailstones (Knight and Knight 1968 b). Callisen (1934, p. 168) also described trapped magma in the feldspar globules in the orbicular facies of a diabase. 
The analogy between hailstones and terrestrial orbiculites becomes almost complete in that protoclastic structures seem to be very common among hailstones (see Knight and Knight 1971, p. 100). Radial growth of ice crystals is always present (see Fig. 9).

Certainly, peculiar and uncommon conditions are needed to form orbiculites in the atmosphere (op. cit., p. 97-98) and in the lithosphere (Sederholm 1928, p. 7; Leveson 1966, p. 422).

\section{The role of oxygen pressure}

It was mentioned (p. 55) that opaque minerals are almost lacking in the orbiculites of Sääkslahti. They seem in general to be scanty in described orbiculites; e.g. among the five occurrences described in more detail by Sederholm (1928), accessory magnetite has been mentioned only in the orbiculite of Hankasalmi $(0.39 \%$ ) and of Pöytyä. The very simple habit of the Pöytyä rock (see op. cit., Fig. 12, p. 46) is perhaps due to spinel nucleation, which inhibited the development of more delicate shells.

The scarcity of crystallization centres seems to be very important for the generation and evolution of orbicules in magmas. Wager (1959, p. 77) states that spinel type minerals nucleate very readily in magmas. Early crystallized spinel (mostly magnetite) acted as centres for the crystallization. Such nuclei being scanty, growth of orbicules resulted, if other requirements were fulfilled. Here again an excellent fit with hailstone formation can be noted: to avoid the damage caused by hailstones, their formation is inhibited by strewing silver iodide crystals on hailstone generating clouds (Knight and Knight 1971, p. 103; see and $c f$. also Yamaguchi and Wada 1972). The lack of nuclei was also the fundamental cause of undercooling, and, consequently, of the formation of the contrasted rhythms of the orbicule shells.

According to Kennedy (1955, p. 501) a low partial pressure of oxygen prevents the forma- tion of early spinels. The content of ferric iron. or the ratio $\mathrm{Fe}_{2} \mathrm{O}_{3} / \mathrm{FeO}$, may be regarded as a rough estimate of the oxygen pressure (see Fudali 1965 , e.g. p. 1073) and the »magnetite-potential» of the magma. It appears from the orbiculite analyses (e.g. Sederholm 1928, Tables I, II, IV, VII, and VIII; Barrière et al. 1971, Table III, p. 404) that the ratio of ferric to ferrous iron is conspicuously low. The orbicular norite of Romsaas is particularly interesting (Sederholm 1928, Table VIII, p. 71). Orbicules in it are very poor in ferric iron $\left(\mathrm{Fe}_{2} \mathrm{O}_{3}=0.50 \%, \mathrm{FeO}=14.50\right.$ $\%$ ). In the matrix the ratio $\mathrm{Fe}_{2} \mathrm{O}_{3} / \mathrm{FeO}$ is somewhat higher $\left(\mathrm{Fe}_{2} \mathrm{O}_{3}=0.22 \%, \mathrm{FeO}=1.59 \%\right)$ and in the surrounding non-orbicular norite it is much higher $\left(\mathrm{Fe}_{2} \mathrm{O}_{3}=3.17 \%, \mathrm{FeO}=8.90\right.$ $\%$ ). At the same time the $\mathrm{Mg} / \mathrm{Fe}_{\text {tot }}$ has diminished. Thus the orbicules crystallized first, and then, with the rising oxygen pressure, the matrix and the ferric-rich norite.

The relatively high content of ferric iron in the spheroids of the Kangasala orbiculite $\left(\mathrm{Fe}_{2} \mathrm{O}_{3}\right.$ $=1.30 \%, \mathrm{FeO}=1.87 \%$; op . cit., Table IV, p. 28) is attributable to the common occurrence of xenolithic orbicule cores.

At first sight orbicular chromites seem to contradict the anti-spinel rule. These rocks are, however, in most cases non-shelled or at best single shelled, and possibly are essentially synneutic in origin.

The occurrence of pyrrhotite in the core of an orbicule in the orbiculite of Kangasala (Sederholm 1928, p. 23 and Fig. 1, Pl. VI) also indicates a low oxygen pressure. That is to say, with the oxidation of ferrous to ferric iron, and the crystallization of magnetite, not enough ferrous iron is left for pyrrhotite to separate and crystallize. As a result of the increase of the partial pressure of oxygen, only magnetite would form:

$3 \mathrm{FeS}+2 \mathrm{O}_{2} \rightarrow \mathrm{Fe}_{3} \mathrm{O}_{4}+\frac{3}{2} \mathrm{~S}_{2}$ (Bartholomé 1957, p. 901).

The crbicular peridotite in the Kylmäkoski nickel ore (P. Isokangas, oral communication, 1972) exemplifies the necessity of a low oxygen pressure both for the formation of magmatic 
$\mathrm{Ni}-\mathrm{Cu}$-sulphide ores and for the formation of orbiculites.

Simonen claims (1966, p. 106) that the decrease of $\mathrm{SiO}_{2}$ during magmatic crystallization is »contradictory to the laws of magmatic differentiation", and orbicular rocks possessing such characteristics must be regarded as metasomatic ones. As stated, a low partial pressure of oxygen is necessary to form orbicules in a magma. Under such conditions, decrease of $\mathrm{SiO}_{2}$ is just what we can expect to happen (see Osborn 1962, especially Fig. 6, p. 223). Likewise, the composition of plagioclase remains constant or may even become more basic (see Ferguson and Wright 1970 , p. 62), the percentage of $\mathrm{Ca}$ and $\mathrm{Al}$ remaining on a high level (see Waters 1955, p. 709, and Wager and Brown 1967, Fig. 107, p. 154). Thus, the An-content of magmatic plagioclase crystals may increase from the core towards the rim (Waters 1955, p. 714; Ferguson and Wright 1970, p. 62) cf. Simonen 1941, p. 123-124).

\section{Significance of radial textures in orbiculites}

Radial arrangement of prismatic and platy crystals is common in terrestrial magmatic orbiculites. Besides plagioclase and biotite, well known from esboitic orbiculites, pyroxene also (Carstens 1957, p. 279), potash-rich alkali feldspars (Bussen and Sakharov 1971; Vorma 1971, p. 22), hornblende (Taubeneck and Poldervaart 1960 , pp. 1302, 1306-07) and olivine (Wager and Brown 1951, p. 166) show the radial arrangement. Zones composed entirely of radial ice crystals are common in hailstones (Fig. 9 in this paper; Knight and Knight 1968 a; see also cover of the »Scientific American», April 1971, associated with the article by Knight and Knight).

Chondrite meteorites have radial pyroxene as a characteristic feature. Besides this analogy with the orbiculites, noted already by the early orbiculite students, chondrite meteorites possess shelled orbicules (see Mason 1962, p. 83; Van
Schmus 1969, Fig. 2, p. 483). A magmatic origin of chondrules seems at least possible (Mason 1962, p. 102).

A spectacular analogy with the radial textures of orbicules is the crescumulate growth pattern in basic layered intrusions (see and $c f$. Wager 1963, p. 2). The peculiar magmatic layering with perpendicular mineral growth, called Willow Lake type rhythmical layering by Taubeneck and Poldervaart (1960, see Figs. 7, 8 and 10, pp. 1306-07 and 1309) illustrates the same principle, and represents in the type locality an important link between igneous layering and orbiculites (Poldervaart and Taubeneck 1959, p. 1396).

Lake ice also crystallizes analogously to crescumulate growth (see e.g. Knight 1962; Lyons and Stoiber 1962). Ice crystals with vertical caxes often form groups with similar orientations (Palosuo 1965, p. 146), just as groups of feldspar crystals grow radially downward from common centres (see Weedon 1960, p. 47).

In fact, the »warp-and-weft» structure of orbicules has counterparts in rhythmic igneous layering and lake ice structures. In the former case, "warp» is represented by perpendicular harrisitic crescumulate growth structures, and »weft» by planar igneous layering (see Wager and Brown 1967, p. 23). In lake ice vertical and horizontal c-axes are dominant, but intermediate positions are rare (Palosuo 1965, pp. 141-46). The mode of formation of the horizontal arrangement of ice crystals is somewhat similar to that of igneous lamination (see Lyons and Stoiber 1962 , pp. 369-70), and the same principle may be applicable to the biotite "weft» of orbicule shells.

It is very probable that free space is necessary to the radial growth of a mineral. From the great number of crystal germs on the solid/liquid interface only those which initially had their maximum-growth crystallographic direction towards the free space were able to grow longer (see Wager and Brown 1967, p. 273; cf. Knight 1962, p. 322, and Lyons and Stoiber 1962, p. 368 and 


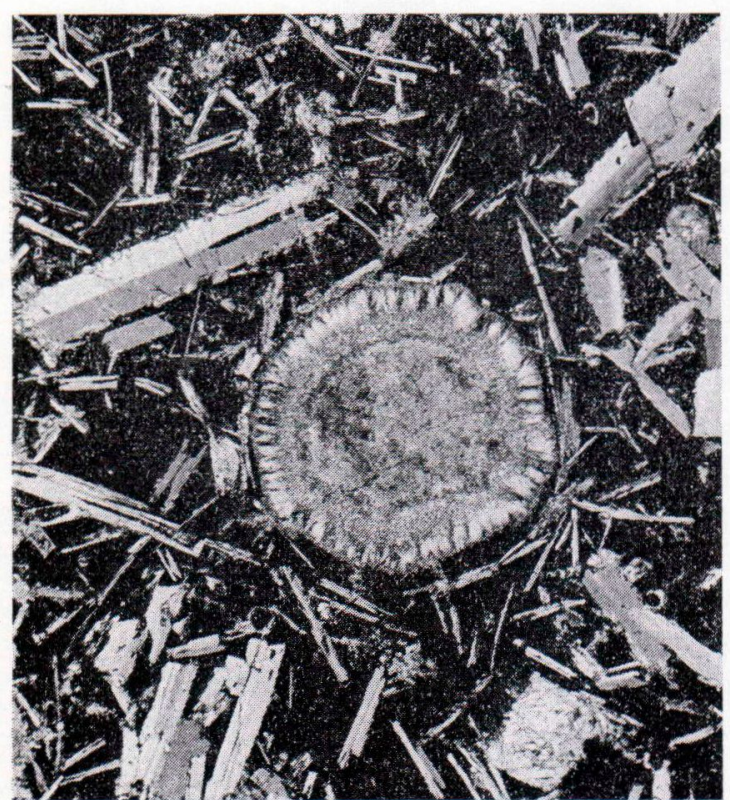

Fig. 10. Chlorite lined amygdule, carbonate core filling $(\varnothing=0.6 \mathrm{~mm})$. From an olivine basalt dyke, Laanila, Inari, Lapland. + nicols.

Photo Erkki Halme.

Fig. 1, p. 369). The direction of heat flow determines the direction of growtht (Knigh 1962 p. 322).

Examples of the radial growth to the free space are very plentiful in nature. In zoned granite bodies rhythmic zoning is parallel to contact surfaces, and quartz crystals in individual rhythms point toward the centre of the body (see Povilaitis 1961). A miniature example of the same kind of »wrong" orbicules are amygdules in volcanic rocks. In Fig. 10 chlorite crystals, lining a vesicle, are directed toward the carbonate filled core. Geodes and mineral druses show the same kind of crystal orientation towards the free space. Oriented crystallization of pegmatite minerals towards the core is well known (see e.g. Volborth 1954, p. 17-18; Haapala 1966, p. 34 and Fig. 14, p. 35; to refer to two Finnish examples).

In the zone melting experiments of KoptevDvornikov and Yaroshevskii (1970, pp. 71213) both pyroxene and anorthite formed radial crystals, oriented parallel to the movement of the advancing melt zone. The necessity of free space for radial crystal growth is demonstrated also by experimental synthesis of amphiboles from melts (see Fedoseev et al. 1966, pp. 107176).

Thus we are assured that the radial growth pattern of minerals is very common in fluid conditions (magmas and hydrothermal environments). On the contrary, radial arrangement is rare, or unknown to me, among metasomatically grown porphyroblasts. Recrystallization can produce radial arrangement (spherulites) but not rhythmically alternating shells.

\section{Discussion: magmatic v. metasomatic orbiculite genesis}

Besides magmatic arbiculites there are evidently also metamorphic and metasomatic ones. It is difficult to evaluate the relative abundance of the magmatic and the essentially solid-state orbiculites, because descriptive terms used in petrography often have genetic implications (e.g. granular/granoblastic, phenocryst/porphyroblast, igneous flow banding/migmatic banding). It seems that true magmatic orbiculites have previously been interpreted incorrectly as metasomatic rocks. For example, Eskola (1938, p. 465) described "phenocryst-like» zoned plagioclase crystals in the cores of orbicules, and further ( $p$. 470), euhedral antiperthitic plagioclase crystals, often Carlsbad twins, from his "model» metasomatic orbiculite of Lintusaari. According to Vance (1969, p. 16) Carlsbad twins are possibly synneusis twins, and they also seem to be restricted almost exclusively to magmatic plagioclases (Gorai 1951, pp. 886-87). Doubt has already been expressed (p. 62) that the migmatic matrixes of some orbiculites have been interpreted incorrectly.

Potash feldspar plays an important role in metasomatic explanations. Why, then, has potash feldspar not formed porphyroblasts as is usual in proved cases of potash metasamotism? In the 
»model» rock of Lintusaari the matrix is strongly enriched in potash feldspar (Eskola 1938), as in all the other orbiculites (e.g. Sederholm 1928, p. 72). In many cases orbicules are totally devoid of potash feldspar, and in those cases where it occurs in orbicules, it is concentrated in the outermost zones (Kangasniemi, Kuru, Sääkslahti). Why were the $\mathrm{K}_{2} \mathrm{O}$-rich fluids, permeating the rocks, not able to penetrate into the orbicules (cf. also Phillips 1973, p. 76)?

In the orbiculites from Sääkslahti plagioclase and hornblende were crystallizing all the time of orbicule formation. Potash became enriched in the residual liquid, and took part in the formation of some of the orbicules when these were almost finished. It crystallized in the interstices of plagioclase in the outer shells of some orbicules. The $\mathrm{K}_{2} \mathrm{O}$-rich zones conform to the other shells and are not »epigenetic». In the matrix potash feldspar locally crystallized first as isometric, angular crystals. Some potash feldspar was left to crystallize last between the other minerals.

It can be said that metasomatists have captured all the potash feldspar: isometric grains could be interpreted as metasomatically grown porphyroblasts, and interstitial microcline just betrays the metasomatizing granitic ichor. What is left to magmatists, after even antiperthitic potash feldspar is confiscated (e.g. by Eskola 1938)? We only can wonder with Routhier (1969, p. 42), why has anhedral interstitial quartz not been accepted as a proof of silica metasomatism?

Unless the protoclastic phenomena are trustworthily explained metasomatically, the isometric and interstitial potash feldspar of the matrix of the Sääkslahti orbiculites should not be used as a double argument for potash metasomatism.

In the following I have presented some criteria for solving the genesis of an individual orbiculite occurrence.

Indications of the magmatic genesis, roughly in the order of validity, are:
1) Protoclastic macro- and microstructures. Late cataclasis is distinguished by associated retrograde alterations. Furthermore, it usually leaves open joints behind. Macroscopic protoclastic deformations are easily distinguished from synmetamorphic and cataclastic dynamometamorphism (see Fig. 7).

2) Association with verifiably magmatic rocks (orbicular chromite ores, and norites, the ovoidophyre of Lujavrurt etc.).

3) Magmatic mineral facies, not corresponding to the regional metamorphic facies conditions in the surroundings. The magmatic facies may be either relict pre-metamorphic (Säälkslahti), or post-metamorphic (orbicular diabase in Bornholm).

4) Magmatic structures and textures (other than those associated with protoclasis). Such are igneous flow banding (Sederholm 1928, p. 44), gravity layering (Barrière et al. 1971, Fig. 1), xenoliths; Carlsbad twinned plagioclase and (other?) signs of synneusis; phenocrysts. In particular, the existence of discordant rhythms in orbicule shells (Sederholm 1928, p. 43; cf. also: Taubeneck and Poldervaart 1960, p. 1302; Knight and Knight 1971, upper figures, p. 101) strongly favours a magmatic genesis. Discordantly superimposed rhythms, as far as I have noted, seem to be quite common among esboitic orbiculites.

5) Different kinds of orbicule cores and shell successions. Negative and positive structures are good proofs for the magmatic genesis; at least they are extremely difficult to explain metasomatically.

6) Radial arrangement of orbicule minerals.

7) Great differences between orbicule and matrix compositions. The mechanism proposed above (pp. 63-64) is essentially similar to zone melting (see Koptev-Dvornikov and Yaroshevskii 1970, p. 710), which causes very strong fractionation (Harris 1957, p. 201-02). 
8) Multishelled orbicules with rhythmic alternation of shell minerals. These are difficult indeed to explain by any kind of metasomatism. Metamorphic concretions, one kind of the few unquestionable solid-state orbiculites, show progressive change of mineral compositions and combinations toward the centre of a concretionorbicule (see Lehtonen 1968). - Orbiculites are surprisingly seldom formed through reactions between xenoliths and magma. Kukharenko et al. (1965, p. 199 and Fig. 132, p. 200) have presented a beautiful example of such a reaction orbiculite. As in the case of metamorphic concretions, chemical instability of the orbicule rawmaterial (calcareous concretions in gneisses, xenoliths in magma) caused the formation of the progressive shell succession. Chemical differences in xenolithic material are readily reflected in mineral combinations of the reaction zones (see Kukharenko et al. 1965, Fig. 132).

9) Lack of petrochemical fit with any kind of metasomatism (chromite ores, hailstones, orbicular norites, etc.).

The following features in an orbiculite occurrence might suggest a metamorphic or metasomatic genesis:

1) Orbicules occur in verifiable schists or paragneisses. Such cases are rare. Thus, the »diorite migmatite» of the Lonesome Mountain orbiculite matrix, with tailed plagioclase "porphyroblasts» (Leveson 1963, Fig. 6, p. 1025), and the »migmatite» matrix of the Lintusaari rock (Eskola 1938 , p. 468) resemble magmatic banding, of which better examples are the orbiculite of l'Aber-Ildut (Barrière et al. 1971) and banded chromite ores, associated with orbicular chromites.

2) Lack of magmatic structures, textures and mineral paragenesis. Contrary to Conybeare (1951, p. 146), I think that metamorphic overprint of the mineral paragenesis, common among orbiculites, is no proof of their metamorphic genesis.
3) Occurrence of similar orbicules through an orbiculite occurrence.

4) Lack of rhythmic alternation of minerals in orbicule shells.

5) Lack of radial textures.

6) Single-shelled orbicules. The most credible metamorphic orbiculites and orbiculite-like rocks, such as the Buffalo Hump rock (Goodspeed 1942) and orbicular hornfelses (e.g. Shakhov 1972, Figs. 6 and 7, pp. $24-25$ ) contain only single-shelled orbicules. Such rocks may have been formed, though, through local melting (see Harker 1908, p. 13), somehow like secondary fluid inclusions in minerals.

Accordingly, in conclusion, from the descriptions, analogy comparisons and discussions presented above, it can be stated that real metamorphic and metasomatic orbiculites occur, but they are more rare and more simple (and visually less attractive!) than magmatic orbiculites, and can be distinguished from these.

\section{Conclusions}

There occur a great number of verifiably magmatic orbiculites. The extreme variation in composition - from hailstones, orbicular chromites and different kinds of calcite-olivine-magnetite orbiculites (Fizhenko 1970; Kukharenko et al. 1965 , p. 251) through orbicular nepheline syenites, (Bussen and Sakharov 1971) to more familiar rocks such as peridotites, norites, gabbros, diabases, diorites, monzonites, quartz monzonites and adamellites (viborgites) - indicate that orbicules can form in almost any kind of magma, if viscosity is low, flow conditions suitable, and the early nucleation of spinel inhibited.

In a fluid magma, with only sparse nucleation centres, phenocrysts were crowded together, forming proto-orbicules. Glomerophyric structures correspond to this early stage of orbiculites. 
Around these mineral groupings, individual phenocrysts, or sometimes xenoliths, attractional and thermal gradients were formed. Subsequent precipitation took place on these nuclei. The excess phase with regard to the eutectic or cotectic composition diffused and crystallized onto the proto-orbicule, forming radial aggregates. As a consequence, the components of another phase or phases became enriched and saturated in the diffusion front, and crystallized as the next shell, often with the first cotectic (or eutectic) pair. Then the first excess phase again began to crystallize from the homogeneous melt.

Supersaturation evidently occurs before precipitation, which is indicated by broad monomineralic shells and alternating monomineralic shells. Two-phase shells represent cotectic or eutectic crystallization.

The mechanism of rhythmic precipitation and growth of radial mineral aggregates is a special case of crescumulate growth, met with in layered igneous rocks. In fact, orbicular varieties are often associated with igneous banding or layering (orbicular chromites, Willow Lake intrusion, orbiculite of l'Aber-Ildut).

It is significant that experimental zone melting and crystallization produces rhythms and radial growth of minerals identical to those of orbiculites. The necessary, and sufficient, condition for the radial growth is free space ahead of growing crystals (plagioclase, alkali feldspar, biotite, pyroxenes, hornblende, olivine, ice). Radial arrangement of minerals is very commonly met with in nature, as in geodes, amygdules, mineral druses, and pegmatite and granite bodies, and it is also produced in silicate synthesis.

The formation of shells ceased with the acidification and increase of viscosity of the residual magma. The crystallization then took place on more local nuclei, in the manner most common in igneous rocks.

The mechanism of orbicule formation outlined above also explains the great differences of the orbicule and matrix compositions, quartz and potash feldspar having been effectively eliminated from orbicules (see Harris 1957).

It is concluded that the features most characteristic of orbiculites - rhythmic layering and radial mineral arrangement - are essentially magmatic.

Acknowledgements - I wish to express my sincerest gratitude to Mr. Charles A. Knight and Mrs. Nancy C. Knight, National Center for Atmospheric Research, Boulder, Colo., for the beautiful hailstone photograph (Fig. 9), reprints and references to hailstone literature. To my teacher in the University of Oulu, Mr. Tauno Piirainen, Ph.D., assistant professor of Geology, I am indebted for his reading of the manuscript. Miss Helen C. Nisbet, MA, B.Sc., Lasswade, Midlothian, Scotland, had a hard task with the English of the manuscript, and deserves my sincerest thanks. Also I should like to thank Mr. Seppo Lahti, B.Sc., for assistance in supplying thin sections and other materials, and Mr. Erkki Halme for the photographs.

\section{REFERENCES}

Barrik̀re, M., Chauris, L. and Cotten, J. (1971) Premières données sur un faciès orbiculaire dans le massif granitique de l'Aber-Ildut (Finistère, France). Bull. Soc. fr. Minéral. Cristallogr. 94, 402-410.

Bartholomé, P. (1957) Theoretical considerations on the separation of the sulphides and their crystallization. Econ. Geol. 52, 895-903.

Beasley, A. E. and McKinney, I. (1973) Prevention of calcium carbonate scale deposition in mill water systems. Mining Engineering 25 (3), 32-37.

Bussen, I. V. and Sakharov, A. S.

БУССЕН, И. В., САХАРОВ, А. С. (1971) Овоидофиры Луяврурта-результат ликвации щелочной магмы. Докл. АН СССР 197, 1402-1405.

Callisen, K. (1934) Das Grundgebirge von Bornholm. Danmarks Geol. Undersøgelse, II, 50.

Carstens, H. (1957) On the orbicular structure in the norite of Romsaas, Norway. Norsk geol. tidsskr. 37, $279-280$.

Conybeare, C. E. B. (1951) An occurrence of orbicular structure, of metasomatic origin, in the Gold Coast. Geol. Mag. 88, 145-147. 
EsкolA, P. (1938) On the esboitic crystallization of orbicular rocks. Jour. Geol. 46, 448-485.

Fedoseev, A. D., Grigor'eva, L. F. and Makarova, T. A.

ФЕДОСЕЕВ, А. Д., ГРИГОРЬЕВА, Л. Ф., МАКАPOВА, Т. А. (1966) Волокнистые силикаты. Прородные и синтетические асбесты. Наука, Москва, Ленинград.

Ferguson, J. and Wright, I. H. (1970) Compositional variation of plagioclases in the Critical Series, Bushveld Complex. In: Symposium of the Bushveld Igneous Complex and other layered intrusions. Geol. Soc. S. Afr., Spec. Publ. 1, 59-66.

Fizhenko, V. V.

ФИґЕНКО, В. В. (1970) О происхождении орбикулярных структур в апатито-кальцито-форстерито-магнетитовых рудах массивов Вуори-Ярви и Горное Озеро. В кн.: Шуркин, К. А. (ред.) Петрология и структурный анализ кристаллических образований, 167174. Наука, Ленинград.

Fudal, R. F. (1965) Oxygen fugacities of basaltic and andesitic magmas. Geochim. Cosmochim. Acta 29, $1063-1975$.

Gon'shakova, V. I.

ГОНЫШАКОВА, В. И. (1961) Трапповый магматизм и магнетитовое оруденение юго-восточной части Сибирской платформы. Труды Института Геологии рудных месторождений, Петрографии, Минералогии и Геохимии, вып. 61 (296 етр.). Изд-во АН СССР, Москва.

Goodspeed, G. E. (1942) Orbicular rock from Buffalo Hump, Idaho. Amer. Mineral. 27, 37-47.

GoraI, M. (1951) Petrological studies on plagioclase twins. Amer. Mineral. 36, 884-901.

HaApala, I. (1966) On the granitic pegmatites in the Peräseinäjoki - Alavus area, South Pohjanmaa, Finland. Bull. Comm. géol. Finlande 224.

Harker, A. (1908) The geology of the small isles of Inverness-Shire (Rum, Canna, Eigg, Muck, etc.) (Sheet 60, Scotland). Mem. Geol. Surv. Scotland.

Harris, P. G. (1957) Zone refining and the origin of potassic basalts. Geochim. Cosmochim. Acta 12, 195-208.

Hressleitner, G. (1951, 1952) Serpentin- und ChromerzGeologie der Balkanhalbinsel und eines Teiles von Kleinasien. Jahrbuch der Geologischen Bundesanstalt, Sonderband 1, 2. Teil. Geologische Bundesanstalt, Wien.

Johnston, W. D. (1936) Nodular, orbicular and banded chromite in Northern California. Econ. Geol. 31, $417-427$.
Kennedy, G. C. (1955) Some aspects of the role of water in rock melts. In: Crust of the Earth. Geol. Soc. America Spec. Paper 62, 489-504.

Knight, C. A. (1962) Studies of Arctic lake ice. Journ. of Glac. 4, 33, 319-335.

- and KNIGHT, N. C. (1968 a) Spongy hailstone growth criteria I. Orientation fabrics. J. Atmos. Sci. 25, 445 -452 .

- and KNIGHT, N. C. (1968 b) Spongy hailstone growth criteria II. Microstructures. J. Atmos. Sci. 25, 453459.

- and KnIght, N. C. (1971) Hailstones. Scientific American, April 1971, 97-103.

Koptev-Dvornikov, E. V. and Yaroshevskii, A. A. КоптЕВ-ДВОРНИКов, Е. В., ЯРОШЕВСКИЙ, А. А. (1970) Экспериментальное моделирование ритмической кристаллизации в системе пироксен-плагиоклаз в связи с происхождением ритмически расслоенных магматических тел. Геохимия, Nㅗ 6, 710-720.

Kukharenko, A. A., Orlova, M. P., Bulakh, A. G., Bagdasarov, E. A., Rimskaya-Korsakova, O. M., Nefedov, E. I., Il'insiri, G. A., Sergeev, A. S. and Aвакumova, N. B.

КУХАРЕНКО, А. А., ОРЛОВА, М. П., БУЛАХ, А. Г., БАГДАСАРОВ, Э. А., РИМСКАЯ- КОРСАКОВА, О. М., НЕФЕДОВ, Е. И., ИЛЬИНСКИЙ, Г. А., СЕРГЕЕВ, А. С., АБАКУМОВА, Н. Б. (1965) Каледонский комплекс ультраосновных, щелочных пород и карбонатитов Кольского полуострова и Северной Карелин. Недра, Москва.

Lehtonen, M. (1968) Tampereen-Hauhon liuskemuodostuman kalkkikonkreetioista. Summary: On the calcareous concretions in the schist area between Tampere and Hauho. Geologi 20, 113-117.

Leveson, D. J. (1963) Orbicular rocks of the Lonesome Mountain area, Beartooth Mountains, Montana and Wyoming. Geol. Soc. America Bull. 74, 1015-1040.

- (1966) Orbicular rocks: a review. Geol. Soc. America Bull. 77, 409-426.

Levi, M. (1970) The synoptics of hail in Israel. Israel J. Earth Sci. 19, 77-83.

List, R., Charlton, R. B. and Butruls, P. I. (1968) A numerical experiment on the growth and feedback mechanisms of hailstones in a one-dimensional steady-state model cloud. J. Atmos. Sci. 25, 10611074.

Lyons, J. B. and Storber, R. E. (1962) Orientation fabrics in lake ice. Journ. of Glac. 4, 33, 367-370.

Macklin, W. C., Merlivat, L. and Stevenson, C. M. (1970) The analysis of a hailstone. Quart. J. R. Met. Soc. $96,472-486$. 
Marmo, V. (1963) Explanation to the map of rocks. Geological map of Finland, Sheet 2232 Keuruu. Geological Survey, Helsinki.

- (1965) Explanation to the map of rocks. Geological map of Finland, Sheet 2214 Virrat. Geological Survey, Helsinki.

Mason, B. (1962) Meteorites. John Wiley \& Sons, New York, London.

Mazur, Z. R. and Zimin, I. A.

МАЗУР, 3. Р., ЗИМИН, И. А. (1964) О новой текстурної разновидности хромита. Геол. рудн. месторонд., 즈 1, 102 - 104.

MEAD, W. J. (1925) The geologic rôle of dilatancy. Jour. Geol. 33, 685-698.

Osborn, E. F. (1962) Reaction series for subalkaline igneous rocks based on different oxygen pressure conditions. Amer. Mineral. 47, 211-226.

Palosuo, E. (1965) Frozen slush on lake ice. Geophysica 9, $131-147$.

Phillips, E. R. (1973) Myrmekites of exsolution and replacement origins - a discussion. Geol. Mag. 110, $74-77$.

Poldervaart, A. and Taubeneck, W. H. (1959) Layered intrusion of Willow Lake type. Geol. Soc. America Bull. 70, 1395-1397.

Povilaitis, M. M.

ПОВИЛАЙТИС, М. М. (1961) О ритмичной зональности некоторых гранттопдных тел. Изв. АН СССР, сер. геол, № 2, 35-49.

Rosenbusch, H. (1887) Mineralien und Gesteine. II. Massige Gesteine. Zweite gänzlich umgearbaitete Auflage. E. Schweizerbartsche Verlagshandlung, Stuttgart.

Routhier, P. (1969) Essai critique sur les méthodes de la géologie (de l'objet à la genèse). Masson et Cie, Paris.

Sederholm, J. J. (1928) On orbicular granites, spotted and nodular granites etc. and on the rapakivi texture. Bull. Comm. géol. Finlande 83.

SHAKHOV F. N.

ШІАХОВ. Ф. Н. (1972) О рудоносности гранитоидных интрузий. В кн.: Ивенсен, Ю. П. (ред.) Рудообразование и его связь с магматизмом, 20-28. Наука, Москва.

Sнams, F. A. (1964) Structures in chromite-bearing serpentinites, Hindubagh, Zhob Valley, West Pakistan. Econ. Geol. 59, 1343-1347.

SHARKov, E. V.

ШАРКОВ, Е. В. (1971) Ритмичная слоистость в расслоенных интрузиях и механизм ее формирования. Изв. АН СССР, сер. геол., № $12,66-74$.
Srmonen, A. (1941) Orbicular rocks in Kemijärvi and Esbo. C. R. Soc. Géol. Finlande 14, 107-142. Bull. Comm. géol. Finlande 126.

- (1966) Orbicular rock in Kuru, Finland. C. R. Soc. Géol. Finlande 38, 93-107. Bull. Comm. géol. Finlande 222.

SukHorukov, Yu. T.

СуХОРУков, Ю. Т. (1972) Некоторые петрогеохимические особенности монцонитов Каджаранского рудного поля. Изв. АН СССР, сер. геол., 77-88.

Taubeneck, W. H. and Poldervaart, A. (1960) Geology of the Elkhorn mountains, Northeastern Oregon: Part 2. Willow Lake intrusion. Geol. Soc. America Bull. 71, 1295-1322.

VAlyashko, M. G. and Agoshkov, V. M.

ВАЛЯАШКО, М. Г., АГОШКОВ, В. М. (1970) Әкспериментально установленные закономерности процесса зонноің плавки в многокомпонентных системах и их геохимическое значение. Вест. Моск. Университета, № $4,26-38$.

VANCE, J. A. (1969) On synneusis. Contr. Mineral. and Petrol. 24, $7-29$.

VAN Schmus, W. R. (1969) Mineralogy, petrology, and classification of type 3 and 4 carbonaceous chondrites. In: Millman, P. M. (Ed.): Metcorite research. Proceedings of a symposium on meteorite research held in Vienna, Austria, 7-13 August 1968, 480-491.

VAN ZyL, C. (1959) An outline of the geology of the Kapalagulu Complex, Kungwe Bay, Tanganyika territory, and aspects of the evolution of layering in basic intrusives. Trans. geol. Soc. S. Afr. 62, 1-29.

Vlasov, K. A., Kuz'menko, M. V. and Es'kova, E. M. (1959) The Lovozero alkali massif. Oliver \& Boyd, Edinburgh and London, 1966.

Volborth, A. (1954) Phosphatminerale aus dem Lithiumpegmatit von Viitaniemi, Eräjärvi, Zentral-Finnland. Ann. Acad. Sci. Fenn. A III 39.

Vorma, A. (1971) Alkali feldspars of the Wiborg rapakivi massif in southeastern Finland. Bull. Comm. géol. Finlande 246.

WAGER, L. R. (1959) Differing powers of crystal nucleation as a factor producing diversity in layered intrusions. Geol. Mag. 96, 76-80.

- (1963) The mechanism of adcumulus growth in the layered series of the Skaergaard intrusion. Min. Soc. America, Special Paper 1, 1-9.

- and Brown, G. M. (1951) A note on rhythmic layering in ultrabasic rocks of Rhum. Geol. Mag. 88, $166-168$. 
W igneous rocks. Oliver \& Boyd, Edinburgh and London.

Waters, A. C. (1955) Volcanic rocks and the tectonic cycle. In: Crust of the Earth. Geol. Soc. America, Spec. Paper 62, 703-722.

WeEdon, D. S. (1960) The Gars-Bheinn sill, Isle of Skye. Quart. J. Geol. Soc. Lond. 116, 37-54.
Wilkman, W. W. (1936) Über Archäische vulkanische Gesteine in Saarijärvi im mittleren Finnland. C. R. Soc. Géol. Finlande 9, 121-130. Bull. Comm. géol. Finlande 115.

YamaGuchI, S. and WADA, H. (1972) On the seed for formation of pyrrhotite. N. Jahrbuch f. Mineralogie. Monatshefte 1972, Heft 9, 430-432.

YAROSHEVSKII, A. A.

ЯРОШЕВСКИЙ, А. А. (1970) О происхождении ритмических структур изверяеншых горных пород. Геохимия, ㅊo $5,562-574$.

Manuscript received, October 18, 1973. 